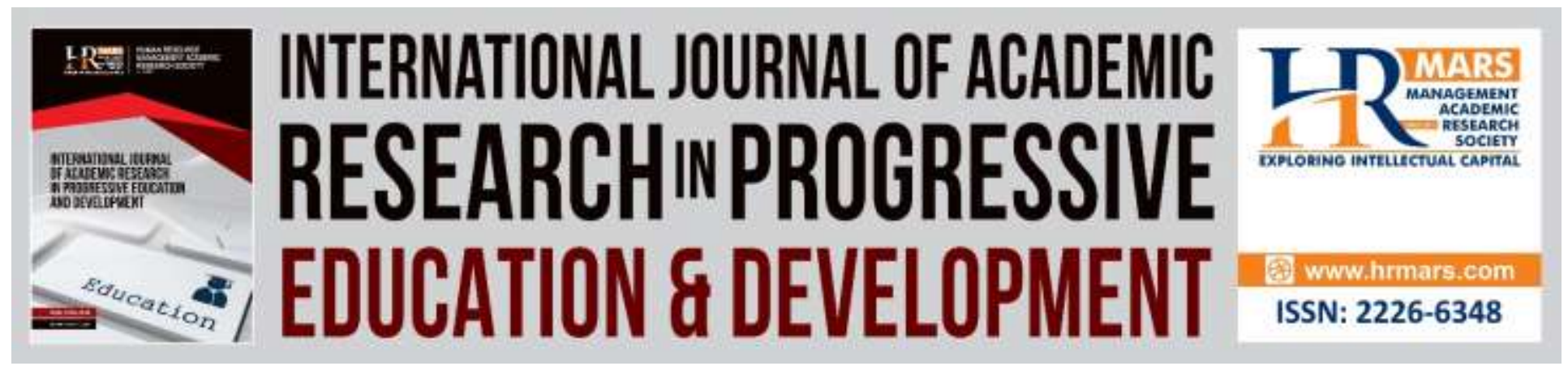

\title{
Development and Evaluation of the 'LIKES' Module to Promote Reading Interest among Orang Asli in Primary Schools
}

Norwaliza Abdul Wahab, Goh Swee Choo, Mohammad Aziz Shah, Ridzwan Jaafar, Nor Hasnida Che Md Ghazali

To Link this Article: http://dx.doi.org/10.6007/IJARPED/v8-i4/6462

DOI: 10.6007/IJARPED/v8-i4/6462

Received: 11 September 2019, Revised: 25 September 2019, Accepted: 09 October 2019

Published Online: 30 October 2019

In-Text Citation: (Wahab, Choo, Shah, Jaafar, \& Ghazali, 2019)

To Cite this Article: Wahab, N. A., Choo, G. S., Shah, M. A., Jaafar, R., \& Ghazali, N. H. C. M. (2019). Development and Evaluation of the 'LIKES' Module to Promote Reading Interest among Orang Asli in Primary Schools. International Journal of Academic Research in Progressive Education and Development, 8(4), 157-164.

Copyright: (C) 2019 The Author(s)

Published by Human Resource Management Academic Research Society (www.hrmars.com)

This article is published under the Creative Commons Attribution (CC BY 4.0) license. Anyone may reproduce, distribute, translate and create derivative works of this article (for both commercial and non-commercial purposes), subject to full attribution to the original publication and authors. The full terms of this license may be seen

at: http://creativecommons.org/licences/by/4.0/legalcode

Vol. 8(4) 2019, Pg. 157- 164

http://hrmars.com/index.php/pages/detail/IJARPED

JOURNAL HOMEPAGE

Full Terms \& Conditions of access and use can be found at http://hrmars.com/index.php/pages/detail/publication-ethics 


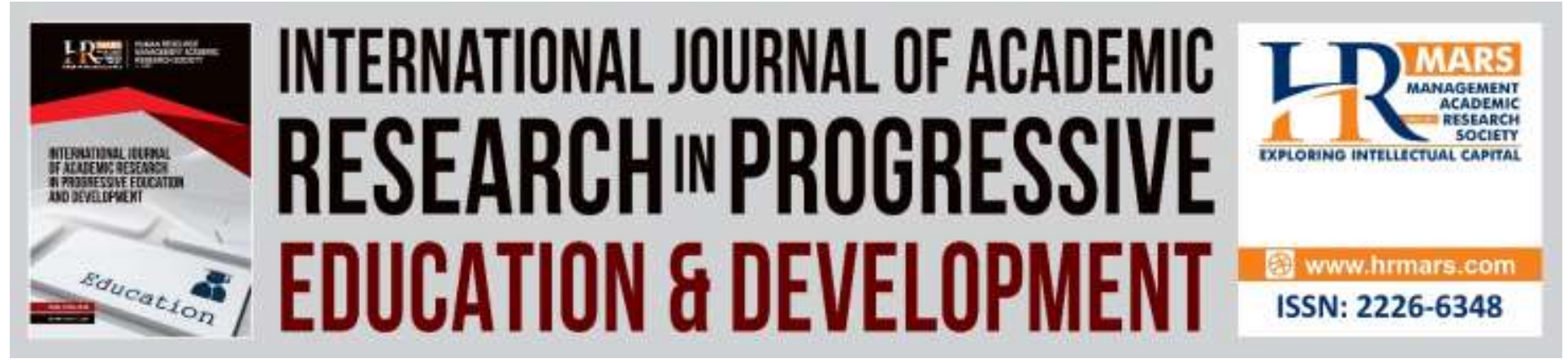

\title{
Development and Evaluation of the 'LIKES' Module to Promote Reading Interest among Orang Asli in Primary Schools
}

\author{
Norwaliza Abdul Wahab, Goh Swee Choo, Mohammad Aziz \\ Shah, Ridzwan Jaafar, Nor Hasnida Che Md Ghazali \\ Universiti Pendidikan Sultan Idris, 35900 Tanjong Malim, Malaysia
}

\begin{abstract}
Literacy is still the main problem in primary schools mainly among Orang Asli students. The level of literacy among Orang Asli students are very low. In the present time, there are many reading modules to help teachers in teaching and learning in preschool and primary school levels. However, modules or reading materials for Orang Asli students are scarce and this makes it difficult for teachers in Orang Asli schools to diversify their teaching and learning methods in a class. Therefore, this research aims to create a module that has a validation and high credibility to help increase a student's grasp in reading. ADDIE model was used as a base to create a model. This research involved five phases which is carrying out an analysis, design, development, implementation and evaluation phase. A survey was conducted to assess the content validity of the module. The data was validated by three experts. The results showed that the LIKES Module for Orang Asli had a high content validity (>74 percent). It meant that this module was validated and ready for use in Orang Asli primary schools to increase their literacy.

Keywords: ADDIE Model, Reading Literacy, LIKES Reading Module, Orang Asli Students, Teaching and Learning.

\section{Introduction}

Education is the main core in determining the advancement and prosperity of a country. Various efforts have been made by the Ministry of Education to ensure literacy in reading is successfully achieved. The Ministry of Education has organized the Educational Restoration Program to help students who face difficulty in Malay Language and Mathematics. Restoration Program is a program intended for students who have difficulty in mastering the basics of reading, writing and calculating due to surrounding factors. This program is carried out by specific teachers in a particular space (Bahagian Pendidikan Khas KPM, 2008).
\end{abstract}

Therefore, students who are at risk of having these three problems such as indigenous students or known as Orang Asli in this paper need special help in the teaching and learning 
process so that they are able to master the three basics. Without special help, they will fail to develop self-confidence to study as well as deprive themselves of the enjoyment in their six years of primary schooling days. By continuing to ignore this problem, Orang Asli students will lose interest and focus to study and will continue to be left behind. Therefore, reading skills is an important element that has to be mastered and be given priority for them to enjoy studying.

Ministry of Education has targeted that all capable students with no difficulty in learning have to be able to master the basics of literacy and numerical before the end of their Phase 1 school term (KPM, 2013). In the effort to master this reading skill, there are still students who are struggling to read as well as students who are unable to read completely, such as Orang Asli students who live in remote areas. This problem should not and must not be persist. More efforts and side programs have to be formulated in order to achieve the Ministry of Education's program. Orang Asli students have to guided, nurtured and motivated continuously so they are able to read alongside their peers.

LIKES Reading Module for Orang Asli contains reading activities that revolves around the daily lives of the Orang Asli community. Alongside with that, all activities and materials are varied by creative teachers which is effective to ensure the goal and pure intention are achieved. LIKES Reading Module for Orang Asli aims to make it easier for weak students to master reading skills, plant the seeds of interest to read and go to school, exposing them to the process of going from simple to challenging reads, help students in building sentences, expand their ways of thinking and guiding them to explore their ability in storytelling through the books they have read. The materials provided is parallel between the aim of reading to understand the text and the content of text that gives meaning to the reader (Othman, 2008).

\section{Problem Statement}

Research regarding literacy skills have discovered that the level of literacy among Orang Asli students are still low (Rasid, 2011). Literacy or reading problems is still a main problem in primary schools (KPM, 2012). Is has become the vision and mission of Wawasan 2020 to produce selfsufficient, knowledgeable and skillful individuals. The Ministry of Education have launched Educational Development Parent Plan (PIPP) which aims to carry out and actualize an educational system that is holistic, progressive, moral and world-class. However, there are few modules and reading materials catered for Orang Asli available and this makes it difficult for teachers in Orang Asli schools to vary their teaching and learning materials in class.

Ma'rof and Sarjit (2008) explained that the factor that leads to the incompetence of Orang Asli in the knowledge aspect to the point that they skip school, is due to the difficulty in cultivating the interest and culture of studying, lack of motivation and spirit to move forward and difficulty in understanding the information given (Ma'rof \& Sarjit, 2008). Shaari, Yusoff, Dali (2016) in their research found that the reason and excuse why Orang Asli students do not master the lesson taught by teachers is because they forget easily and the reading materials provided to them does not spark an interest for them to engage in learning (Sani, 2014). Ministry of Education is very concerned of this matter when this issue of literacy of Orang Asli students was added to the nation's educational agenda such as National Key Results Area and Education Development Plan 
Wave 12013 - 2015. With that series, multiple programs have been drafted and implemented by the MOE such as PROTIM, PROBIM, KIA2M and LINUS to overcome this issue.

According to General Guidebook of Primary School Integrated Curriculum 2003, it shows that that each student is different with each other in aspect of experience, manner, practice, talent and capability. Students who face difficulty in learning are those who experience circumstantial restrictions and that's why they cannot distinguish or relate objects when they go to school. Lack of experiences also contributes to the negative impact towards the development of syllables and thinking growth of children. Therefore, research by Sani (2014) puts forward a suggestion to the Education Ministry to allocate expert teachers to handle LINUS students in schools that have Orang Asli students, preparing a more suitable module which namely accommodates Orang Asli students and aids teachers, conduct workshops for parents of Orang Asli students so they are able to help their children at home as well as allocate funds specifically for the LINUS Program. However, even until to today, the reading module for Orang Asli students are limited and difficult to acquire. In relation that, the aim of this research is to create a reading module for Orang Asli students by taking into account the view of teachers who teach Orang Asli students based on students' level and interest.

\section{Research Objectives}

This research aims to create a reading module to guide teachers in increasing Orang Asli students' ability to read. This paper is to explain the usage of an ADDIE model in the development of LIKES Reading Module for Orang Asli students. The module emphasizes on reading based on syllables. Developing LIKES Reading Module is important to help Orang Asli students who are weak in reading so they can master the skill of reading as well as overcome illiteracy in this country.

\section{Methodology}

LIKES Reading Module is built based on ADDIE Model. This model is a design model which functions as a guideline towards the development of software and teaching and learning materials based on necessities. This model is one of the teaching models that is often used as a base for other teaching model designs. ADDIE Model is a generic process that needs to be modified before it can be used, the function of this model is designed in a way to develop a teaching and learning method so that the presentation of a certain lesson will be more effective and efficient. ADDIE Teaching Model covers phases such as analysis, design, development, execution and evaluation. This core elements of ADDIE MODEL by Seels \& Glasgow (1990) can be seen in Figure 1. 


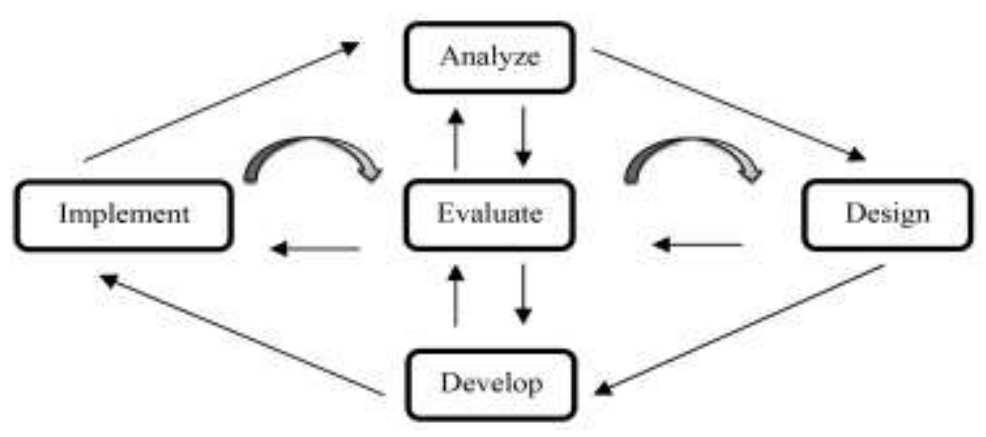

Figure 1. Core elements of ADDIE model (Seels \& Glasgow, 1990).

Qualitative method involves literature research analysis in the creation of conceptual research framework, interviews with teachers as well as observations in classrooms. While a quantitative method will be carried out to obtain data regarding the effectiveness of the module as well as the involvement and interest of students. In the first phase of research, document analysis will be given to revise and check documents. According to Bowen, document analysis is a systematic procedure to revise or evaluate documents either through printing or electronic (Bowen, 2009). Some of the documents that will be revised systematically are books, brochures, student records in schools, files, newspaper cuttings and information from websites. A semistructure interview will be carried out in the qualitative phase of this research.

This instrument enables researchers to obtain information that have not been taken into consideration prior to this as it gives the respondents freedom to come up with ideas and perceptions about this reading module for Orang Asli. Interview questions were taken from document analysis. Interviews are very helpful in getting information based on the experience of teachers. In next phase, questionnaire review will be carried out by researchers based on results of the interview. Interview data will be analyzed to determine the theme that has been set and the codes that will be the guide in creating the questionnaire. This questionnaire consists of a series of questions that will be asked to individuals to obtain information statistically about the identified topic (Creswell, 2013).

The method of teaching and learning that is implemented in this module also aims to make it easier for teachers to teach as it is suitable to be used according to students' capability and it has been arranged in a systematic manner. The reading activity will be fun because the concept is based on their daily lives and storyline sequence revolves around the activities and experience that they face every day with their families and friends. The activities planned in the LIKES module are favorable and easy to be carried out in a relaxed and enjoyable lesson form as well as portray interesting images based on the storyline. This module also aids teachers to vary the teaching and learning process in classrooms. Hopefully LIKES Reading Module for Orang Asli can spark new ideas that are more interesting and innovative among teachers teaching in Orang Asli schools so they can place these weak students on par with their mainstream peers. 


\section{PHASE I: Analysis Phase}

The ADDIE Model started with the analytic phase, which often included the assessment of needs, clarification of problems and establishment of goals (Gustafon \& Branch, 2017). The first phase of this research was done by carrying out literature research analysis and creation of conceptual research framework. This phase also will focus on collecting data through discussions and brainstorming ideas with teachers who teach Orang Asli students regarding activities that will be added into the module and determining the things that will be necessary for teachers to carry out the teaching and learning process in Orang Asli schools.

\section{PHASE II: Design Phase}

The design phase concerned the design of objectives, specification of activities, analyses of the subject matter, and planning of lessons. It also included the determination of the methods to be used, with reference to the objectives. Theme that arises from the analysis document through the literature design will be used in designing the Orang Asli reading module framework.

\section{PHASE III: Development Phase}

In the designing phase, the methods of instructional delivery were chosen, the learning objectives created, and the theory to be implemented in the module selected. Subsequently, the development phase entailed the preparation of lesson plans and activities for eleven sessions. Data collected in Phase I and II will be used to help the module expansion process.

\section{PHASE IV: Implementation Phase}

After thoughtful analysis, designing and development, the instructions should then be implemented. Next, creating and determining the validity of module, getting validation from experts and evaluating the validity of module. Then, making improvements based on experts' suggestions. Determining the credibility of module by carrying out preliminary research on teachers in Orang Asli schools.

\section{PHASE V: Evaluation Phase}

Effectiveness of module is tested based on Orang Asli students' capability to master skills and their interest in classrooms. Eight teachers from eight schools were chosen to carry out LIKES reading module for Orang Asli. Data will be collected through questionnaire to see the effectiveness of program as well as students' interest. During the implementation of the LIKES module, formative evaluations occurred when the experts supervised the teachers and gave comments for improvement. The researcher then revised the module and made some changes according to the comments. Next, the experts demonstrated the proper way to teach in the lessons. Then, the teachers took over the same for the rest of the session. As for the summative evaluations, several students were interviewed to obtain their feedback pertaining to the module. 
Vol. 8, No. 4, 2019, E-ISSN: $2226-6348$ @ 2019 HRMARS

\section{Results}

Results of the content validity of the module show that, the overall score was $74 \%$. Since the score was $>70 \%$, the contents validity of the LIKES reading module had good validity (see Table 1). A content validity of $>70$ percent was considered to be high (Appoo, 2009; Jasmi et al., 2015).

Table 1. Content Validity of LIKES Reading Module

\begin{tabular}{llll}
\hline No & Statement & Percent & Expert Review \\
\hline \multirow{2}{*}{ This module meets population target } & $70 \%$ & Accept \\
2 & This module can be implemented perfectly & $76 \%$ & Accept \\
3 & This module can improve reading skills & $74 \%$ & Accept \\
4 & This module can attract students to read & $78 \%$ & Accept \\
& Total & $74 \%$ & \\
\hline
\end{tabular}

\section{Conclusions}

The module applied in the LINUS program was observed to be not understandable by Orang Ali students because the activities in module are too general and is difficult for Orang Asli students because they have no basic foundation and it makes the teaching and learning process harder. The ADDIE model provided a basis for the development of education modules, was easy to use, and could be implemented in the school curricula. Therefore, a suitable module for Orang Asli students would be when the surrounding aspects and their level of skills are taken into account as it will indirectly solidify the literacy skills among students. In conclusion, the execution of the teaching and learning process for reading skills has to continue to be carried out efficiently so that the efforts to increase the mastering of reading, writing and calculating, especially reading, among students will be achieved. The role of teachers is very important in guiding students in obtaining the reading skills. Besides that, the creation of this Orang Asli reading module in this research also aims to help Orang Asli students' performance in Malay Language in primary school. Then, the scope of this research can be widened and sharpened to carry out further research as suggested. This is very important and meaningful in in helping various parties to achieved the best results.

\section{Acknowledgements}

The first author acknowledges the cooperation of the research participants and thanks Research Management and Research Centre (Research Code: 2018-0031-107-01), Sultan Idris Education University, for the Grant that partially supports this study.

\section{Corresponding Author}

Norwaliza Abdul Wahab, Department of Educational Studies, Universiti Pendidikan Sultan Idris, 35900 Tg Malim, Perak, Malaysia. Email: drnorwaliza@gmail.com 
INTERNATIONAL JOURNAL OF ACADEMIC RESEARCH IN PROGRESSIVE EDUCATION AND

DEVELOPMENT

Vol. 8, No. 4, 2019, E-ISSN: $2226-6348$ @ 2019 HRMARS

\section{References}

Appoo, P. (2009). Development and Evaluation of Moral Reasoning Module for the Teaching and Learning of Moral Education. Ph.D. Thesis. Pulau Pinang: University Sains Malaysia, 2009.

Bahagian Pendidikan Khas Kementerian Pelajaran Malaysia. (2008). Maklumat Pendidikan Khas. Kuala Lumpur: Kementerian Pelajaran Malaysia.

Bowen, G. A. (2009). Document analysis as a qualitative research method. Qualitative research journal, 9(2), 27-40. Doi: 10.3316/QRJ0902027.

Creswell, J. (2013). Steps in Conducting a Scholarly Mixed Methods Study. DBER Speaker Series, paper 48. Retrieved from http://digitalcommons.unl.edu/dbspeakers/48.

Gustafson, K. L., \& Branch, R. M. (2017). What Is Instructional Design? In R. A. Reiser, \& J. V. Dempsey (Eds.), Trends and Issues in Instructional Design and Technology (pp. 10-16). New Jersey: Pearson Education.

Jamian, A. R. (2016). Permasalahan kemahiran membaca dan menulis Bahasa Melayu muridmurid sekolah rendah di luar bandar. Jurnal Pendidikan Bahasa Melayu, 1(1), 1-12.

Kementerian Pelajaran Malaysia, "NKRA Kementerian Pelajaran Malaysia". Download on 11 Oktober 2012. Retrieve from http://pmr.penerangan. gov.my/index.php/isunasional/466pengenalan-nkra/4808-pointers-6- bidang-keberhasilan-utama-negara-nkra.html, 2010.

Kementerian Pendidikan Malaysia. (2013). Pelan Pembangunan Pendidikan Malaysia 20132025. Putrajaya

Ma'rof, R., \& Sarjit, S. (2008). Orang asli: isu, transformasi dan cabaran. Selangor: Universiti Putra Malaysia.

Othman, Y. (2008). Proses dan strategi membaca berkesan. Kuala Lumpur: Universiti Putra Malaysia.

Sani, N. (2014). Pelaksanaan program literasi \& numerasi (LINUS): satu analisis. PhD thesis, University of Malaya.

Seels, B., \& Glasgow, Z. (1990). Exercises in Instructional Design. Colombus, Ohio: Merill Publising Company.

Shaari, A. S., Yusoff, N., Ghazali, M. I., \& Dali, M. H. (2016). Kanak-kanak minoriti Orang Asli di Malaysia: menggapai literasi bahasa Melayu. Jurnal Pendidikan Bahasa Melayu, 1(2), 5970.

Talib, J. A., Mohamad, Z., \& Wahab, N. A. (2015). Validity and Reliability of Careeer Exploration Module. Middle East Journal of Scientific Research, 23, 2639-2644. 